\title{
Pengaruh Perilaku Asertif Terhadap Stress Kerja Pada Karyawan Pt. Indoturbine Jakarta
}

\author{
Suhartini* \\ Oryza Sativa Reswari**
}

\begin{abstract}
The research aims to reveal: (I) Effect of partial and simultaneous behavior of verbal and non verbal assertive response to stress in the work of employees of PT. Indoturbine Jakarta, (2) Determine which variable is more influential on assertive behavior to the stress of work at the employees of PT. Indotribune, Jakarta

Census method was employed in this study while questionnaires and literature study were chosen in gathering data. The analysis includes descriptive analysis (respondent characteristics and assessment of each variable) and statistical analysis ( $F$ test and $t$ test).

The results showed that: ( $(1)$ there is a simultaneous effect, positive and significant correlation between Assertive Behavior (Verbal Ability and Non-Verbal Ability) of the Employee Stress PT. Indoturbine, Jakarta, (2) there is a partial influence of variable Assertive Verbal Ability of the Stress of work and there is a partial variable influence Assertive Non-Verbal Ability of the work stress, and (3) Verbal Ability Assertive behavior is the most influential variable of the Working Stress employees of PT. Indoturbine, Jakarta.
\end{abstract}

Keywords: Assertive behavior, stress of work and employees

\section{Pendahuluan}

Dalam pelaksanaan kerjanya, seorang karyawan tidak hanya berhubungan dengan sesama karyawan saja, tetapi juga berhubungan dengan atasannya dalam hal ini yaitu direktur, manajer, unit lain, rekan sekerja dan peraturan yang ada di kantor. Lingkungan pekerjaan, tuntutan tugas, beban kerja, hubungan interpersonal dan struktur organisasi dapat menjadi tekanan terhadap dirinya. Tekanan-tekanan di atas apabila dianggap sebagai stresor negatif, dapat memicu timbulnya stres pada pekerjaan.

* Dosen Fakultas Ekonomi UII.

** Alumni Fakultas Ekonomi UII. 
PT. Indoturbine yang bergerak dalam bidang teknologi dipengaruhi oleh teknologi, pendidikan, pengembangan serta komunikasi terhadap jaringan staf berkompeten dan berdedikasi, menjadikan dukungan perusahaan agar tetap bertahan dan berkompetisi dengan perusahaan lainnya. Setiap individu dan semua tingkatan perusahaan menginginkan agar semua karyawan dapat melakukan pekerjaan dan memiliki kemampuan interkasi sosial dengan baik yang menjadikan hubungan yang produktif dalam team-work dengan karyawan lain.

Mengingat pentingnya interaksi sosial yang bersifat interpersonal, yang ditandai dengan komunikasi yang efektif oleh karena itu karyawan/pegawai haruslah dapat bersifat terbuka dalam mengemukakan pendapat maupun dalam bersikap, serta mampu menerima hal-hal yang sama terhadap orang lain. Dalam hal ini karyawan dituntut untuk memiliki perilaku asertif. Perilaku asertif adalah suatu perilaku interpersonal yang mengandung pengungkapan pikiran dan perasaan secara jujur dan relatif langsung yang dilakukan dengan mempertimbangkan perasaan dan kesejahteraan fihak lain yang bersangkutan. Orang dengan perilaku asertif menghargai hak-hak pribadi sendiri dan hak-hak orang lain. Individu tidak mau harga dirinya dilanggar, demikian pula harga diri orang lain.

Orang-orang yang asertif pada umumnya mampu mengadakan dan membina hubungan yang akrab dan hangat dengan orang lain, mampu menyatakan perasaan dan pikiran-pikirannya dengan tepat dan jujur tanpa memaksanya pada orang lain. Individu yang asertif juga mampu menghargai perasaan-perasaan dan pendapat-pendapat orang lain, sehingga dalam hubungan antar pribadi mampu bertukar pengalaman, pikiran, dan perasaan. Orang-orang yang berlaku asertif lebih banyak menerima tanggapan positif dan merasa lebih dimengerti oleh orang lain, sehingga jarang mengalami gangguan depresi, karena apabila menghadapi masalah biasanya dapat menyatakannya dengan tepat kepada orang lain.

Dengan demikian orang-orang yang mempunyai perilaku asertif mendapat banyak keuntungan seperti keuntungan memperoleh jalan keluar, mendapat dukungan sosial, dan dapat melepaskan beban mental akibat masalahnya itu. Dengan kata lain tingkatstress cenderung rendah sebaliknya orangyang berperilaku non asertif akan merasa kesulitan untuk beradaptasi dan bersosialisasi dengan lingkungan tempat kerja, baik yang berkaitan dengan hubungan interpersonal, tuntutan pekerjaan, dan beban pekerjaannya. Dalam keadaan demikian karyawan akan cenderung mengalami stress kerja yang lebih tinggi. Dalam konteks profesi yang akan diteliti, karyawan yang mempunyai perilaku asertif akan lebih dapat beradaptasi dengan situasi dan kondisi pekerjaannya. 


\section{Rumusan Masalah}

1. Adakah pengaruh simultan perilaku asertif verbal dan non verbal terhadap stress kerja di karyawan PT. Indoturbine?

2. Adakah pengaruh parsial perilaku asertif verbal dan non verbal terhadap stress kerja di karyawan PT. Indoturbine?

3. Variabel mana yang lebih berpengaruh pada perilaku asertif terhadap stress kerja di karyawan PT. Indotribune?

\section{Landasan Teori}

Menurut Rich \& Schoeder (1992), perilaku asertif merupakan ketrampilan ekspresif yang terdiri dari komponen respon verbal dan non yerbal yang ditujukkan dalam situasi hubungan interpersonal dan mengandung resiko yang berupa reaksi negatif dari orang yang menerima. Perilaku asertif adalah ekspresi yang langsung, jujur dan pada tempatnya, dari pikiran, perasaan, kebutuhan atau hak-hak pribadi tanpa kecemasan yang tidak beralasan. Langsung artinya perilaku tidak berputar-putar, pesan yang disampaikan jelas, fokus, wajar dan tidak menghakimi. Jujur artinya kata-kata, gerak gerik dan perasaan, semuanya mengatakan hal yang sama. Pada tempatnya berarti memperhitungkan hak-hak atau perasaan orang lain maupun diri sendiri pada waktu dan tempat yang tepat.

Sementara itu, Menurut Fensterheim \& Baer (1980) dapat diketahui bahwa pribadi yang asertif dapat memiliki 4 (empat) ciri antara lain adalah:

1. Merasa bebas untuk mengemukakan diri sendiri melalui kata-kata dan tindakan, mampu mengungkapkan pernyataan : inilah diriku, inilah yang saya rasakan.

2. Dapat berkomunikasi dengan orang lain dari semua tingkatan baik orang yang tidak dikenal, sahabat ataupun keluarga, selalu terbuka, langsung dan jujur.

3. Mempunyai pandangan aktif tentang hidup, mengejar apa yang diinginkan dan berusaha untuk memprolehnya.

4. Bertindak dengan cara yang dihormatinya sendiri karena sadar bahwa dirinya tidak dapat selalu menang maka ia menerima keterbatasannya, akan tetapi ia selalu berusaha mencapai sesuatu dengan usaha yang sebaik -baiknya.

Menurut Smith (1975) mengemukakan bahwa perilaki asertif memiliki dua macam kemampuan, yaitu:

1. Kemampuan Verbal

a. Broken Record, merupakan kemampuan yang didapat dengan cara mengulang dengan perlahan, mengatakan apa yang anda inginkan secara berulang-ulang sehingga individu tidak terjebak dalam sisi verbal yang manipulatif argumentasi dan hal-hal yang tidak logis. 
b. Fogging, merupakan kemampuan untuk menerima kritikan dengan tenang.

c. Free Information and Self Disclosure, merupaka kemampuan memahami isyarat-isyarat sederhana yang diberikan orang lain dan percakapan sehari-hari.

d. Negative Assertion, merupakan kemampuan menerima kesalahan yang kita buat sendiri, mau menerima kritikan terhadap kualitas diri yang negative pada perilaku kita sendiri, tanpa rasa cemas ataupun mengabaikan kesalahan tersebut.

e. Negative Inquiri, merupakan kemampuan seseorang untuk aktif memberikan kritik dan menggunakan informasi tersebut (bila menyimpang). Hal itu mendorong seseorang untuk mengungkapkan perasaan negatifnya dengan jujur sehingga memperbaiki komunikasinya dengan orang lain.

f. Workable Compromise, dapat diterapkan bila self-respect seseorang tidak berada dalam keragu-raguan.

2. Kemampuan Non Verbal

Seseorang yang asertif umumnya memperlihatkan kontak mata dengan baik, berdiri atau duduk yang nyaman tanpa kegelisahan dan berbicara dengan suara yang mantap tanpa terkesan teriakan atau kekuatan

Menurut Cawod (1997), perilaku asertif mendukung tercapainya tujuan untuk membangun suatu tim yang bekerja bersama-sama secara efektif, yaitu:

1. Menjaga proses komunikasi agar tetap lancar

Dengan menggunakan ketrampilan asertif bermaksud agar dialog tetap terbuka, memberikan informasi baru dan pikiran-pikiran serta perasaanperasaan yang jujur mengalir secara bolak-balik.

2. Membangun sikap saling menghormati

Sikap hormat adalah kunci bagi kualitas masukan bagi orang lain dan dari anda sendiri. Membangun sikap saling menghormati mengembangkan harga diri bagi kedua belah pihak. Perilaku asertif dengan demikian mempunyai dua tujuan yaitu: menjaga proses komunikasi agar tetap lancar dan membangun sikap saling menghormati.

Stres didefinisikan oleh Handoko (1993) adalah suatu kondisi ketegangan yang mempengaruhi emosi, proses berpikir dan konidsi seseorang, sehingga stress yang terlalu besar dapat mengancam kemampuan seseorang untuk menghadapi lingkungan. Stres kerja dapat terjadi sewaktu individu menghadapi tuntutan situasi serta kondisi dalam pekerjaan yang dirasa terlalu berat, melakukan pekerjaan dengan penuh ketegangan, menuntut konsentrasi, konflik dengan atasan atau rekan sekerja, perlakuan tidak adil, tidak puas dengan pendapatan, 
dan lain sebagainya sesuai dengan persepsi masing- masing individu. Namun stres yang dialami individu satu dengan yang lain berbeda-beda meskipun sumber stresnya sama. Segala macam bentuk stres pada dasarnya disebabkan oleh kekurangmengertian manusia akan keterbatasan dirinya, ketidakmampuan untuk melawan keterbatasan inilah yang dapat menimbulkan frustrasi, gelisah, konflik dan rasa bersalah yang merupakan tipe-tipe dasar stres.

Dalam dunia kerja apapun jabatannya diperlukan perilaku asertif dalam menekuni pekerjaannya. Hal tersebut diperlukan untuk mengekspresikan pikiran, perasaan, sikap terhadap problema - problema yang dihadapi, dengan demikian akan timbul fleksibilitas dan adaptabilitas dalam mensikapi dan kondisi kerjanya. Ketrampilan sosial yang ditunjukkan dalam perilaku asertif mendorong seseorang untuk dapat lebih cepat menjalin hubungan sosial, beradaptasi, menyesuaikan diri dengan lingkungan, baik lingkungan sosial maupun di tempat individu bekerja.

Orang yang berperilaku non asertif akan merasa kesulitan untuk beradaptasi dan bersosialisasi dengan lingkungan tempat kerja, baik yang berkaitan dengan hubungan interpersonal, tuntutan pekerjaan, 'beban pekerjaan, peraturan organisasi atau gaya kepemimpinan di tempat kerja. Munculnya perilaku non asertif ini disebabkan kurangnya kepercayaan pada diri sendiri, takut akan resiko dan mengambil tanggung Jawab dalam kondisi yang tidak nyaman atau kurang menyadari sepenuhnya hak-hak yang dimiliki. Dalam keadaan demikian karyawan akan cenderung menjalani stres kerja yang lebih tinggi.

\section{Kerangka Pemikiran}

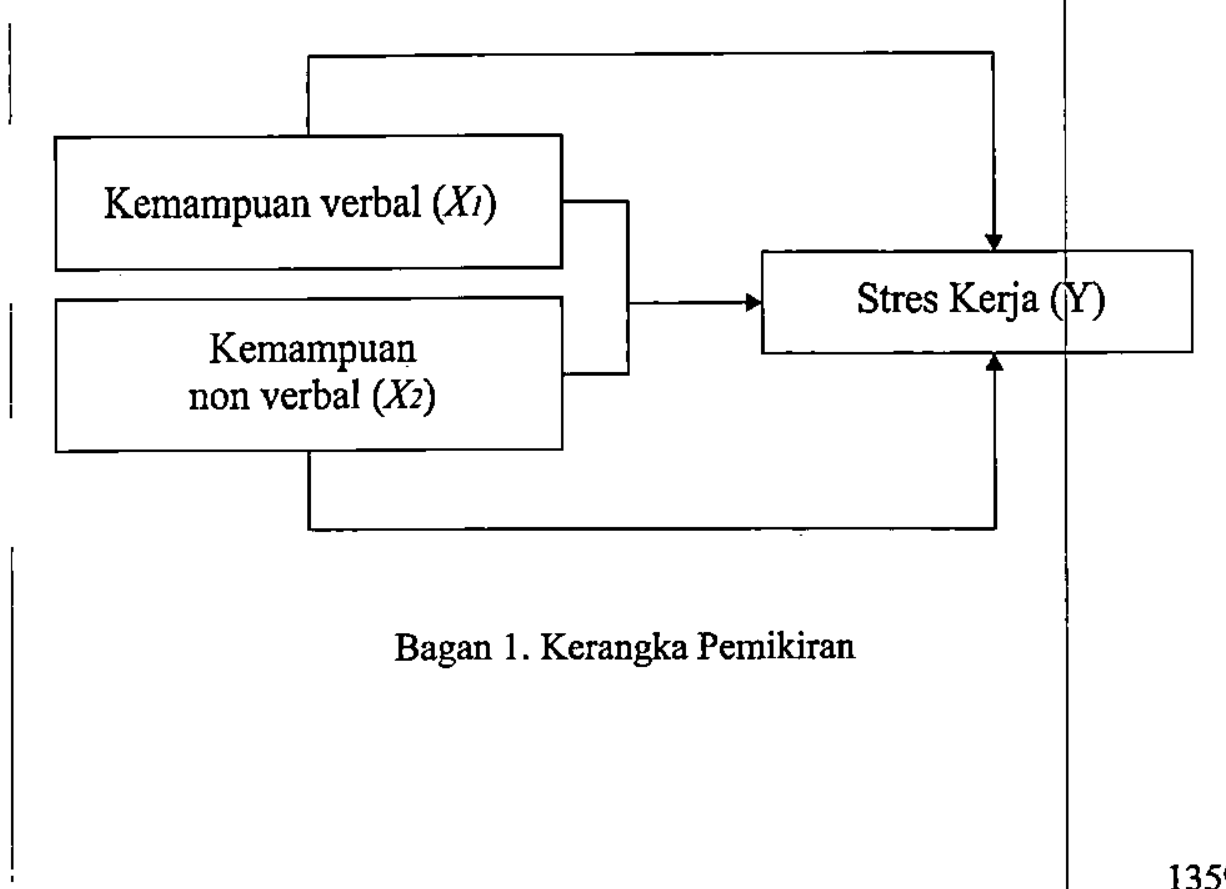




\section{Hipotesis}

1. Diduga perilaku asertif berpengaruh secara simultan pada stress kerja terhadap karyawan PT. Indoturbine

2. Diduga perilaku asertif berpengaruh secara parsial pada stress kerja terhadap karyawan PT. Indoturbine

3. Diduga perilaku asertif kemampuan verbal paling berpengaruh terhadap stress kerja pada karyawan PT. Indoturbine

\section{F. Metode Penelitian}

\section{Lokasi Penelitian}

Lokasi penelitian yang dipilih oleh peneliti adalah PT. Indoturbine yang beralamatkan di Gedung Landmark Tower A, Lantai 10, Jl. Jendral Sudirman, Jakarta.

\section{Indikator Variabel Penelitian}

Perilaku Asertif Kemampuan Verbal $\left(\mathrm{X}_{1}\right)$, indikatornya adalah : mampu mengungkapkan perasaan positif, tidak membenarkan setiap pendapat, mampu mengungkapkan segala sesuatu tentang dirinya, menyatakan ketidaksetujuan, menghargai orang lain, bertanya tentang sesuatu hal, mampu mempertahankan diri, mampu mengakhiri suatu pecakapan dengan baik, menggunakan kata-kata tepat, meminta penjelasan, tegas dalam menghadapi situasi dan menerima kritikan

Perilaku Asertif Kemampuan Non Verbal $\left(\mathrm{X}_{2}\right)$, indikatornya adalah: postur tubuh rileks menghadapi orang lain, posisi kepala tegak saat berbicara dengan lawan bicara, memiliki suara tegas, tertawa saat adanya humor dan suara datar saat membuat pernyataan

Indikator stres $(\mathrm{Y})$ adalah : ruang kerja yang memiliki penerangan yang baik, memiliki lubang udara yang cukup, tempat kerja yang memiliki temperature udara yang nyaman, leluasanya tempat kerja, situasi tempat kerja cukup tenang, partner kerja yang menyenangkan, adanya peraturan yang jelas dalam organisasi, hubungan structural yang jelas, pembagian tugas yang seimbang, hubungan dengan keluarga, kondisi keuangan keluarga 
Suhartini \& Orya Sativa Reswari, Pengaruh Perilaku Asertif terhadap Stress......

\section{Analisis Data Dan Pembahasan}

Kuesioner disebarkan kepada 50 orang responden dan yang responden yang mengembalikan dan mengisi kuesioner secara lengkap hanya sebanyak 40 orang.

\section{Analisis Deskriptif}

Analisis deksirptif ini meliputi analisis karkateristik responden dan analisis penilaian responden terhadap variabel penelitian.

\section{1.) Analisis Karakteristik Responden}

Tabel 1

Karakteristik Responden

\begin{tabular}{|c|c|c|}
\hline Jenis Kelamin & Frekuensi & Persentase (\%) \\
\hline Perempuan & 25 & $62.5 \%$ \\
\hline Laki-laki & 15 & $37.5 \%$ \\
\hline (1) & 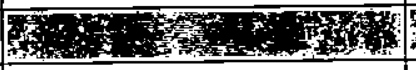 & 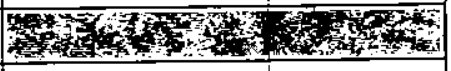 \\
\hline Usia & Jumlah & Prosentase (\%) \\
\hline$<=25$ tahun & 5 & $12.5 \%$ \\
\hline $26-36$ tahun & 10 & $25.0 \%$ \\
\hline$>36$ tahun & 25 & $62.5 \%$ \\
\hline 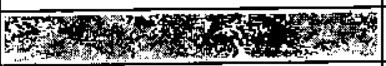 & 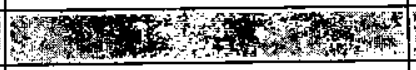 & 13 \\
\hline Status & Jumlah & Prosentase (\%) \\
\hline Sudah menikah & 32 & $80.0 \%$ \\
\hline Belum menikah & 8 & $20.0 \%$ \\
\hline 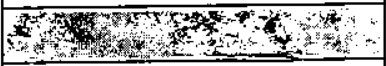 & 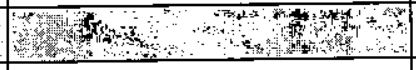 & 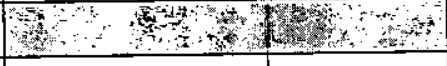 \\
\hline Lama Kerja & Jumlah & Prosentase (\%) \\
\hline$<=5$ tahun & 10 & $25 \%$ \\
\hline $6-10$ tahun & 8 & $20 \%$ \\
\hline$>10$ tahun & 22 & $55 \%$ \\
\hline 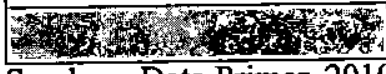 & 3 & 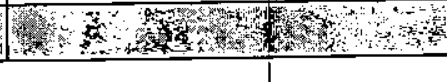 \\
\hline
\end{tabular}

Sumber : Data Primer, 2010

\section{2.) Penilaian Responden Terhadap Variabel Penelitian}

Penilaian ini didasarkan pada nilai rata-rata variabel, dengan ketentuan penilaian adalah sebagai berikut :

$\begin{array}{lll}1,00-1,75 & = & \text { Penilaian sangat rendah } \\ 1,76-2,50 & = & \text { Penilaian rendah } \\ 2,51-3,25 & = & \text { Penilaian tinggi } \\ 3,26-4,00 & = & \text { Penilaian sangat tinggi }\end{array}$




\section{A. Variabel Asertif Kemampuan Verbal}

Tabel 2

\begin{tabular}{|c|l|c|c|}
\hline \multicolumn{1}{l}{ Hasil Deskriptif Variabel asertif kemampuan verbal } \\
\hline No & \multicolumn{1}{|c|}{ Indikator Asertif Kemanpan Verbal } & Mean & Kategori \\
\hline 1 & Mampu menyampaikan perasaan senang dengan baik & 3.20 & Tinggi \\
\hline 2 & Mampu berkata tidak untuk sesuatu yang tidak benar & 3.18 & Tinggi \\
\hline 3 & Mampu mengungkapkan perasaan dengan baik & 2.95 & Tinggi \\
\hline 4 & Bisa menolak atas pendapat orang lain & 3.13 & Tinggi \\
\hline 5 & Diam jika mendengarkan pendapat orang lain & 3.23 & Tinggi \\
\hline 6 & Bertanya pada sesuatu yang tidak dimengerti & 3.25 & Tinggi \\
\hline 7 & Mamapu mempertahankan argumen & 3.13 & Tinggi \\
\hline 8 & Mampu menyelesaikan kalimat dengan baik & 3.13 & Tinggi \\
\hline 9 & Mampu menempatkan kata - kata yang tepat & 3.13 & Tinggi \\
\hline 10 & Meminta penjelasan atas sesuatu yang tidak dimengerti & 3.30 & Sangat Tinggi \\
\hline 11 & Berani melarang orang yang merokok di area rumah sakit & 2.95 & Tinggi \\
\hline 12 & Menerima segala kritikan & 3.15 & Tinggi \\
\hline $\begin{array}{l}\text { Rata-rata } \\
\text { Jawaban }\end{array}$ & & 3.14 & Tinggi \\
\hline
\end{tabular}

Sumber : Data Primer Yang Diolah, 2010

Berdasarkan Tabel 2 dapat dilihat bahwa variabel asertif kemampuan verbal dinilai dengan rata-rata skor sebesar 3,14, (tinggi). Hal ini menunjukkan bahwa semua karyawan dapat melakukan pekerjaan dan memiliki kemampuan interkasi sosial dengan baik yang menjadikan hubungan yang produktif dalam team-work dengan karyawan lain. Mengingat pentingnya interaksi sosial yang bersifat interpersonal, yang ditandai dengan komunikasi yang efektif oleh karena itu karyawan/pegawai haruslah dapat bersifat terbuka dalam mengemukakan pendapat maupun dalam bersikap, serta mampu menerima hal-hal yang sama terhadap orang lain. 


\section{B. Variabel Asertif Kemampuan Non Verbal}

Tabel 3

Hasil Deskriptif Variabel asertif kemampuan non verbal

\begin{tabular}{|c|l|c|c|}
\hline No & Indikator Asertir Kemampuan Non Verbal & Ming & \\
\hline 1 & Memeluk orang yang dicintai & 3.20 & Tinggi \\
\hline 2 & Selalu rileks dalam mengadapi orang disekitar & 3.18 & Tinggi \\
\hline 3 & Selalu menatap lawan bicara & 2.95 & Tinggi \\
\hline 4 & Bicara dengan suara tegas & 3.13 & Tinggi \\
\hline 5 & Tertawa apabila mengetahui sesuatu yang lucu & 3.23 & Tinggi \\
\hline 6 & Suara datar jika menyampaikan sesuatu & 3.25 & Tinggi \\
\hline $\begin{array}{l}\text { Rata-rata } \\
\text { Jawaban }\end{array}$ & & 3.14 & Tinggi \\
\hline
\end{tabular}

Sumber : Data Primer Yang Diolah, 2010

Berdasarkan Tabel 3 dapat dilihat bahwa penilaian terhadap variabel asertif kemampuan non verbal dengan rata-rata skor sebesar 3,14 (tinggi). Hal ini menunjukkan bahwa karyawan telah mampu mengungkap emosi secara terbuka, jujur, tegas dam langsung pada tujuan sebagai usaha untuk mencapai kebebasan 'emosi dan dilakukan dengan penuh keyakinan diri dan sopan. Karyawan yang memiliki perilaku asertif dengan bahasa tubuhnya misalnya memeluk orang dicintai, rileks menghadapi customer atau sesama rekan kerja, dan berbicara dengan sopan maka karyawan tersebut akan lebih dihargai orang lain, menjadi lebih percaya diri dan memiliki rasa puas.

Hasil analisis deskriptif per indikator menunjukkan penilaian terhadap terendah pada item selalu menatap lawan bicara. Karyawan yang tidak berani menatap lawan bicara biasanya terjadi ketika ia berbicara dengan atasannya atau lawan jenis, karena dalam budaya bangsa kita atau budaya timur masalah tata krama dan sopan santun masih dipegang teguh dalam lingkungan masyarakat, misalnya adanya adat bahwa yang lebih muda ketika berbicara dengan yang lebih tua harus dengan cara menunduk atau tidak boleh menatap mata lawan bicara secara langsung karena akan terlihat tidak sopan atau adanya keyakinan atau kepercayaan agama tertentu bahwa berbicara dengan lawan jenis tidak boleh menatap secara langsung. Oleh karena sebaiknya karyawan melakukan perbaikan dalam pembentukan kepribadian sehingga mamapu melakukan komunikasi interpesonal dengan baik dalam lingkungan organisasi. 


\section{Variabel Stres Kerja}

Tabel 4

Hasil Deskriptif Variabel Stress Kerja

\begin{tabular}{|c|c|c|c|}
\hline No & P & Meang & KKategori \\
\hline 1 & Penerangan cukup & 3.13 & baik \\
\hline 2 & Ventilasi baik & 2.85 & baik \\
\hline 3 & Temperatur udara sangat nyaman & 2.83 & baik \\
\hline 4 & Meja kerja cukup nyaman dan luas & 2.85 & baik \\
\hline 5 & Ketenangan di tempat kerja terjaga & 3.05 & baik \\
\hline 6 & Memiliki partner kerja menyenangkan & 2.98 & baik \\
\hline 7 & Peraturan jelas & 3.03 & baik \\
\hline 8 & Jabatan-jabatan yang jelas dalam lingkungan kerja & 2.80 & baik \\
\hline 9 & Pembagian tugas seimbang & 2.80 & baik \\
\hline 10 & Memiliki hubungan kekeluargaan yang baik & 3.23 & baik \\
\hline 11 & Financial keluarga cukup & 2.85 & baik \\
\hline $\begin{array}{l}\text { Rata-rata } \\
\text { Jawaban } \\
\end{array}$ & & 2.94 & Kondusif \\
\hline
\end{tabular}

Sumber : Data Primer Yang Diolah, 2010

Berdasarkan Tabel 4 diatas dapat dilihat bahwa penilaian terhadap variabel stres kerja memiliki rata-rata skor sebesar 2,94 (kondusif). Hasil ini menunjukkan bahwa stres kerja karaywan PT. Indoturbine baik, artinya karyawan dalam bekerja merasa nyaman, tidak memperoleh tekanan, dan didukung suasana lingkungan kerja yag baik, misalya penerangan cukup, udara segar, dan ruang kerja yang nyaman. Namun demikian pembagian tugas yang seimbang masih dirasa paling rendah oleh karyawan. Untuk itu perlu adanya kerjasama yang baik antara sesama karyawan maupun dengan atasan, misalnya dengan meningkatkan briefing/rapat kecil dengan bawahan sebelum memulai pekerjaan terutama dalam pembagian tugas secara adil disesuaikan dengan tingkat kemampuan karaywan maupun kesulitannya, hal ini penting mengingat karyawan di PT. Indoturbine harus mampu bekerja dalam teamwork, sehingga hambatan-hambatan yang dirasakan karyawan dapat diatasi sejak dini. Dengan adanya pembagian tugas yang jelas maka diharapkan stres kerja atau tekanan yang dialami oleh karyawan dapat diminimalisir. 
Suhartini \& Orya Sativa Reswari, Pengaruh Perilaku Asertif terhadap Stress......

\section{3). Analisis Statistik}

Tabel 4

Hasil Regresi Linier Berganda

\begin{tabular}{|c|c|c|c|c|c|c|c|}
\hline $\begin{array}{c}\text { Variabel } \\
\text { Independent }\end{array}$ & $\begin{array}{c}\text { Koef } \\
\text { Regresi }\end{array}$ & $\begin{array}{c}\text { Koef Beta } \\
\text { (Standardized) }\end{array}$ & $\begin{array}{c}\text { r } \\
\text { t statistic }\end{array}$ & $\begin{array}{c}\text { Adj. R } \\
\text { Square }\end{array}$ & F & Sig.F \\
\hline (Constant) & 0.522 & & 1.074 & 0.290 & 0,397 & 13.940 & 0.000 \\
\hline $\mathrm{X} 1$ & 0.478 & 0.395 & 2.822 & 0.008 & & & \\
\hline $\mathrm{X} 2$ & 0.301 & 0.371 & 2.653 & 0.012 & & & \\
\hline
\end{tabular}

Sumber : Data Primer Yang Diolah, 2010

Persamaan regresi dengan model koefisien standardized :

$$
Y 1=0,522+0,395 X 1+0,371 \times 2
$$

Tabel 4 menunjukkan hasil koefisien determinasi pada model regresi model 1 (Adjusted $\mathrm{R}^{2}$ ) sebesar 0,397, maka dapat diartikan bahwa 39,7 persen stres kerja karyawan dapat dijelaskan oleh variabel asertif kemampuan verbal dan asertif kemampuan non verbal. Sedangkan sisanya sebesar 60,3 persen dipengaruhi oleh variabel lain yang tidak dimasukkan dalam model penelitian.

Tabel 4 menunjukkan bahwa $F_{\text {hiumg }}$ sebesar 13,840 dan probabilitas (Sig-F) sebesar $0,000<0,05$. Hal ini menunjukkan bahwa probabilitas kurang dari taraf signifikansi $5 \%(\mathrm{p}<0,05)$, maka Ha diterima dan menolak Ho. Ini menunjukkan bahwa variabel asertif kemampuan verbal dan asertif kemampuan non verbal, secara simultan berpengaruh signifikan terhadap stres kerja karyawan PT. Indoturbine Jakarta. Berdasarkan uji $\mathrm{F}$ tersebut menunjukkan bahwa hipotesis pertama yang menyatakan "Terdapat pengaruh secara simultan variabel asertif yang terdiri dari asertif kemampuan verbal, dan asertif kemampuan non verbal, terhadap stres kerja karyawan PT. Indoturbine Jakarta" terbukti.

Hasil pengujian pada variabel asertif kemampuan verbal diperoleh koefisien beta (Standaridized) sebesar 0,395 dan probability (sig-t) sebesar $0,008<0,05$. Hasil ini berarti Ho ditolak yang berarti terdapat pengaruh secara signifikan asertif kemampuan verbal terhadap stres kerja karyawan. Hasil koefisien regresi 'yang positif $(0,395)$ menunjukkan bahwa semakin tinggi asertif kemampuan verbal maka stres kerja akan semakin baik, dan sebaliknya semakin rendah asertif kemampuan verbal maka stres kerja akan semakin rendah. Hasil pengujian pada variabel asertif kemampuan non verbal diperoleh koefisien beta (Standaridized) sebesar 0,371 dan probability (sig-t) sebesar 0,012<0,05. Hasil ini berarti Ho 'ditolak yang berarti terdapat pengaruh secara signifikan asertif kemampuan non verbal terhadap stres kerja karyawan. Hasil koefisien regresi yang positif $(0,371)$ 
menunjukkan bahwa semakin tinggi asertif kemampuan non verbal maka stres kerja akan semakin baik, dan sebaliknya semakin rendah asertif kemampuan non verbal maka stres kerja akan semakin rendah. Jadi, berdasarkan uji t di atas mènunjukkan bahwa hipotesis kedua yang menyatakan "Terdapat pengaruh secara parsial variabel asertif yang terdiri dari asertif kemampuan verbal dan asertif kemampuan non verbal, terhadap stres kerja karyawan PT. Indoturbine Jakarta" terbukti.

Hasil koefisien determinasi parsial untuk asertif kemampuan verbal sebsar 0,177 dan asertif kemampuan non-verbal sebesar 0,160. Dengan demikian untuk variabel faktor asertif kemampuan verbal $\left(\mathrm{X}_{1}\right)$ paling berpengaruh terhadap stres kerja karyawan PT. Indoturbine Jakarta. Hal ini berarti hipotesis ketiga yang menyatakan bahwa "Diduga asertif kemampuan verbal paling berpengaruh terhadap stres kerja karyawan di PT. Indoturbine" dapat dibuktikan.

\section{4.) Pembahasan Hasil Penelitian}

Hasil penelitian ini menunjukkan bahwa baik secara simultan maupun parsial terdapat pengaruh antara variabel asertifyang terdiri dari asertifkemampuan verbal dan asertif kemampuan non verbal terhadap stres kerja karyawan PT. Indoturbine Jakarta Stres kerja dapat terjadi sewaktu individu menghadapi tuntutan situasi atau kondisi pekerjaan yang dirasa terlalu berat, melakukan pekerjaan dengan penuh ketegangan, adanya konflik dengan atasan atau rekan sekerja, menerima perlakuan tidak adil, tidak puas dengan pendapatan yang diterima, dan lain sebagainya sesuai dengan persepsi masing-masing individu. Menurut Kahn \& Cooper (1993), harus dipahami bahwa stres yang dirasakan individu satu berbeda dengan yang lain, meskipun sumber stresnya sama hal tersebut sebagian besar tergantung pada keadaan kepribadian yang dimiliki. Hasil penelitian ini sesuai dengan hasil penelitian L. Sulistiawati. O (2005) yang menyimpulkan bahwa variabel asertivitas dan persepsi gaya kepemimpinan transformasional sebagai prediktor terhadap stress kerja karyawan RS. Bethesda Yogyakarta.

Perilaku asertif adalah suatu perilaku interpersonal yang mengandung pengungkapan pikiran dan perasaan secara jujur dan relatif langsung, yang dilakukan dengan mempertimbangkan perasaan dan kesejahteraan pihak lain. Orang dengan perilaku asertif menghargai hak-hak pribadi sendiri dan hak-hak orang lain. Individu tidak mau harga dirinya dilanggar, demikian pula harga diri orang lain. Perilaku asertif dikatakan telah diterapkan apabila individu merasa memiliki rasa percaya diri yang tinggi dan pandangan positif terhadap dirinya dan orang lain. Menurut Towned (1991) posisi hidup yang dimiliki adalah "I'm Ok, You Are Ok", berani mengambil tanggung Jawab atas dirinya sendiri, 
individu yang asertif memiliki motivasi melakukan pekerjaan dengan baik, memperhatikan perasaan dan mau mendengarkan ide-ide yang disampaikan oleh pihak lain, jujur dan terbuka serta mau bertanya. Individu ini lebih dapat mempengaruhi, mendengarkan dan bernegosiasi, sehingga orang lain memilih untuk bekerja sama dengan rela tanpa ada paksaan.

Hasil ini juga sesuai dengan pendapat Kanfer \& Goldstein (1980) orang-orang yang asertif pada umumnya mampu mengadakan dan membina hubungan yang akrab dan hangat dengan orang lain, mampu menyatakan perasaan dan pikiranpikirannya dengan tepat dan jujur tanpa memaksanya pada orang lain. Individu yang asertif juga mampu menghargai perasaan-perasaan dan pendapat-pendapat orang lain, sehingga dalam hubungan antar pribadi mampu bertukar pengalaman, pikiran, dan perasaan. Orang-orang yang berlaku asertif lebih banyak menerima tanggapan positif dan merasa lebih dimengerti oleh orang lain, sehingga jarang mengalami gangguan depresi, karena apabila menghadapi masalah biasanya dapat menyatakannya dengan tepat kepada orang lain. Sedangkan orang yang berperilaku non asertif akan merasa kesulitan untuk beradaptasi dan bersosialisasi dengan lingkungan tempat kerja, baik yang berkaitan dengan hubungan interpersonal, tuntutan pekerjaan, beban pekerjaan, peraturan organisasi atau gaya kepemimpinan di tempat kerja. Dalam keadaan demikian karyawan akan cenderung menjalani stres kerja yang lebih tinggi

McNeilage \& Adams (dalam Arianti, 1992) menyatakan bahwa perilaku asertif selain berguna untuk mengembangkan diri individu, secara tidak langsung juga berpengaruh terhadap lingkungan tempat individu tersebut mengembangkan dirinya. Perilaku asertif akan meningkatkan kemampuan beradaptasi yang baik dengan lingkungan di sekitarnya. Penyesuaian yang baik dengan sendirinya akan membawa pada kualitas hidup yang baik pula.

Semakin asertif seseorang maka ia semakin mampu untuk mengelola stres kerja agar tidak merugikan dirinya dan lingkungan kerjanya. Seseorang yang menderita stres kerja mengisyaratkan bahwa ia tidak asertif, yang ditunjukkan |dengan ketidakmampuannya beradaptasi dengan tuntutan-tuntutan di lingkungan kerjanya, baik yang berasal dari tuntutan tugas, tuntutan peran dan tuntutan interpersonal dalam mengurangi stress kerja.

Asertif kemampuan verbal paling berpengaruh terhadap stres kerja karyawan di PT. Indoturbine. Kemampuan asertif verbal ditunjukkan dengan adanya perasaan senang, mampu mengungkapkan apa yang dirasakan, berkata jujur, dan mampu menempatkan kata - kata yang tept dalam pembicaraan. Seorang 'karaywan yang mampu mengungkapkan perasaannya dan mampu berkata jujur maka akan terjalin hubungan interpesonal yang baik dalam organisasi sehingga ada perasaan nyaman dalam menjalankan pekerjaannya sehingga karyawan dapat 
mengatur atau memanajeman stres kerja, hal ini tentunya akan berdampak baik bagi organisasi.

Menurut Fensterheim \& Baer (1980) orang-orang yang asertif adalah orang yang langsung jujur dan ekspresif, merasa percaya diri, memiliki harga diri, dan membuat orang lain merasa berharga dan berarti. Sebaliknya orang yang agresif orang yang mungkin membuat orang merasa malu dan orang yang tidak asertif menimbulkan sikap menaruh kasihan dan menghina.

Menurut Lloyd (1990) kemampuan asertif non verbal seseorang umumnya memperlihatkan kontak mata dengan baik, berdiri atau duduk yang nyaman tanpa kegelisahan dan berbicara dengan suara yang mantap tanpa terkesan teriakan atau kekuatan. Karyawan yang memiliki kemampuan asertif non verbal biasanya memiliki kepercayaan diri yang kuat, sehingga akan mempengaruhi setiap keputusan yang diambil dalam organisasi. Rasa confidance atau percaya diri yang kuat dalam diri karyawan artinya tingkah laku penuh ketegasan yang timbul karena adanya kebebasan emosi dan keadaan efektif yang mendukung. misalnya: menyatakan hak-hak pribadi, berbuat sesuatu untuk mendapatkan hak tersebut, melakukan hal tersebut sebagai usaha untuk mencapai kebebasan emosi.

Selain penting untuk menyatakan pendiriannya hendaknya juga diimbangi dengan bentuk penghormatan kepada orang lain. Menurut Cawod (1997) sikap hormat adalah kunci bagi kualitas masukan bagi orang lain dan dari anda sendiri. Membangun sikap saling menghormati mengembangkan harga diri bagi keđua belah pihak. Perilaku asertif dengan demikian mempunyai dua tujuan yaitu: menjaga proses komunikasi agar tetap lancar dan membangun sikap saling menghormati

Namun demikian masih ada karyawan yang enggan bersikap asertif, hal ini terbukti karyawan memberikan penilaian yang rendah pada item mampu mengungkapkan perasaan dengan baik, karena dalam dirinya ada rasa takut mengecewakan orang lain, takut jika akhirnya dirinya tidak lagi disukai ataupun diterima. Selain itu alasan "untuk mempertahankan kelangsungan hubungan" juga sering menjadi alasan karena salah satu pihak tidak ingin membuat pihak lain sakit hati. Padahal, dengan membiarkan diri untuk bersikap tidak asertif (memendam perasaan), justru akan mengancam hubungan yang ada karena salah satu pihak kemudian akan merasa dimanfaatkan oleh pihak lain.

Berdasarkan hasil secara deskriptif pada variabel asertif kemampuan verbal menunjukkan bahwa pegawai PT. Indoturbine memberikan penilaian terendah pada berani mengungkapkan perasaan dengan baik dan berani melarang orang yang merokok di lingkungan perusahaan. Kurangnya keberanian pegawai dalam mengungkapkan tidak pada sesuatu yang benar mungkin karena masih adanya rasa tidak enak atau dalam bahasa Jawa "pekewuh" terhadap sesama rekan kerja. 
Hendaknya pihak perusahaan mulai membiasakan budaya disiplin dan tertib artinya jika di lingkungan kantor semua peraturan atau tata tertib hendaknya dilaksanakan dengan baik, misalnya ada larangan untuk tidak merokok di dalam ruangan maka peraturan itu benar-benar diterapkan, sehingga hal ini dapat memotivasi karyawan memberikan teguran kepada karyawan lain yang telah melanggar tata tertib kantor tanpa ada rasa bersalah atau tidak nyaman.

Berdasarkan hasil secara deskriptif pada variabel asertif kemampuan non verbal menunjukkan bahwa pegawai PT. Indoturbine memberikan penilaian terendah pada selalu menatap lawan bicara. Karyawan yang tidak berani menatap lawan bicara biasanya terjadi ketika ia berbicara dengan atasannya atau lawan jenis, karena dalam budaya bangsa kita atau budaya timur masalah tata krama dan sopan santun masih dipegang teguh dalam lingkungan masyarakat, misalnya adanya adat bahwa yang lebih muda ketika berbicara dengan yang lebih tua harus dengan cara menunduk atau tidak boleh menatap mata lawan bicara secara langsung karena akan terlihat tidak sopan atau adanya keyakinan atau kepercayaan agama tertentu bahwa berbicara dengan lawan jenis tidak boleh menatap secara langsung. Oleh karena sebaiknya karyawan melakukan perbaikan dalam pembentukan kepribadian sehingga mamapu melakukan komunikasi interpesonal dengan baik dalam lingkungan organisasi.

Berdasarkan dari uraian diatas, dapat disimpulkan untuk meningkatkan kemampuan asertif karyawan agar menjadi lebih baik perusahaan sebaiknya memberikan kebebasan kepada semua karyawan untuk menyampaikan pendapat, maupun mengungkapkan perasaannya baik perasaan senang maupun tidak senang, sehingga hal ini akan mendorong karaywan untuk berani mengungkapkan perasaannya, caranya misalnya secara periodik mengadakan pertemuan, rapat, atau breafing untuk membahas perkembangan perusahaan. Selain itu lebih ditingkatkan hubungan interpesonal antara karyawan maupun dengan atasan dengan mengadakan kegiatan diluar kantor, misalnya rekreasi, atau outbond bersama sehingga akan terjalin hubungan yang baik dalam organisasi tersebut. 


\section{Kesimpulan}

1. Terdapat pengaruh secara simultan pada perilaku asertif terhadap stress kerja pada karyawan PT. Indoturbine Jakarta.

2. Terdapat pengaruh secara parsial pada perilaku asertif yang terdiri dari kemampuan verbal dan kemampuan non verbal terhadap stress kerja karyawan PT. Indoturbine Jakarta.

3. Kemampuan verbal paling berpengaruh terhadap stress kerja karyawan PT. Indoturbine Jakarta.

\section{Saran}

1. Berikan kebebasan kepada semua karyawan untuk menyampaikan pendapat maupun perasaannya.

2. Tingkatkan hubungan interpesonal antara karyawan maupun dengan atasan melalui kegiatan non-formal.

3. Bagi peneliti selanjutnya disarankan untuk memperluas dan memperdalam indikator-indikator, menerapkan pada objek penelitian yang lain dan menggunakan variabel bebas lainnya seperti gaya kepemimpinan transformasional, sehingga didapatkan perilaku asertif yang maksimal. 


\section{DAFTAR PUSTAKA}

Baer, J., \& Freinsterhem, H. (1980). Jangan Bilang Ya Bila Anda Akan Mengatakan Tidak. Jakarta: Penerbit Gunung.

Cooper, G.L., Cooper, R.D. \& Eaker, L.H. (1988). First Edition. Lifing with stress. England: The Penguin Group

Handoko, H.C. (1993). Manajemen Personalia dan Sumber daya Manusia. Edisi kedua. Yogyakrta: BPFE.

Lloyd, S.R (1990). Mengembangkan Perilaku Asertif Yang Positif. Alih Bahasa: Budiyanto, F.K. Jakarta: Binarupa Aksara.

Sulistiawati, L. 2005. Hubungan Perilaku Asertif dan Persepsi Gaya Kepemimpinan Transformasional dengan Stres Kerja Penelitian Terhadap Karyawan RS Bethesda,Yogyakarta. Tesis (tidak diterbitkan) Yogyakarta: Fakultas Psikologi Universitas Gadjah Mada 